\title{
Influence of Substrate Water Content and Daily Light Integral on Photosynthesis, Water Use Efficiency, and Morphology of Heuchera americana
}

\author{
Katherine F. Garland ${ }^{1}$ \\ University of Maine Cooperative Extension, 307 Maine Avenue, Bangor, ME 04401 \\ Stephanie E. Burnett \\ Department of Plant, Soil, and Environmental Sciences, University of Maine, 5722 Deering Hall, \\ Orono, ME 04469 \\ Michael E. Day \\ School of Forest Resources, University of Maine, 5755 Nutting Hall, Orono, ME 04469 \\ Marc W. van Iersel \\ Department of Horticulture, The University of Georgia, 1111 Miller Plant Sciences Building, \\ Athens, GA 30602
}

\begin{abstract}
AdDitional INDEX wORDs. american alumroot, coral bells, foliage plant, gas exchange, stomatal conductance, transpiration
Abstract. Two investigations were conducted to determine the morphological and physiological impacts of varying light and substrate water levels on Heuchera americana 'Dale's Strain' (american alumroot). Both investigations used a capacitance sensor automated irrigation system to maintain constant substrate volumetric water contents $(\theta=$ volume of water/volume of substrate). In the first study, the substrate was maintained at one of eight $\theta$ ranging from 0.15 to $0.50 \mathrm{~L} \cdot \mathrm{L}^{-1}$. Leaf area of plants grown at the highest $\theta$ was more than twice that of plants grown at the lowest $\theta$. Shoot dry weight also responded positively to $\theta$ increasing from 0.15 to $0.35 \mathrm{~L} \cdot \mathrm{L}^{-1}$, but plants did not have greater dry weights when maintained at $\theta$ higher than $0.35 \mathrm{~L} \cdot \mathrm{L}^{-1}$. The second experiment assessed american alumroot's performance under four daily light integrals (DLIs) $\left(7.5,10.8,14.9\right.$, and $\left.21.8 \mathrm{~mol} \cdot \mathrm{m}^{-2} \cdot \mathrm{d}^{-1}\right)$ with $\theta$ maintained at $0.35 \mathrm{~L} \cdot \mathrm{L}^{-1}$. Increasing DLI from 7.5 to $21.8 \mathrm{~mol} \cdot \mathrm{m}^{-2} \cdot \mathrm{d}^{-1}$ caused shoot dry weight, leaf area, maximum width, and leaf count to change quadratically. Dry weight and leaf area reached their maximum at $10.8 \mathrm{~mol} \cdot \mathrm{m}^{-2} \cdot \mathrm{d}^{-1}$, whereas leaf count was greatest at $14.9 \mathrm{~mol} \cdot \mathrm{m}^{-2} \cdot \mathrm{d}^{-1}$. Increasing DLI to $21.8 \mathrm{~mol} \cdot \mathrm{m}^{-2} \cdot \mathrm{d}^{-1}$ negatively impacted leaf area and leaf count but did not lower shoot dry weight. Leaf area ratio and petiole length of the uppermost fully expanded leaf decreased with increasing DLI. Measures of leaf-level net photosynthesis, light response curves, and $\mathrm{CO}_{2}$ response curves indicated no physiological differences among plants grown under different water or light levels. In both studies, long-term, whole crop measures of water use efficiency based on shoot dry weight and water applied $\left(W_{U} E_{c}\right)$ did not reflect the same water use trends as instantaneous, leaf-level measures of WUE based on leaf gas exchange $\left(W U E_{1}\right)$. WUE $E_{c}$ decreased with increasing $\theta$ and DLI, whereas $\mathrm{WUE}_{1}$ was not influenced by $\theta$ and increased with increasing DLI. WUE $\mathrm{E}_{1}$ is often used to provide insight as to how various abiotic and biotic factors influence how efficiently water is used to produce biomass. However, these findings demonstrate that there are limitations associated with making such extrapolations.
\end{abstract}

Increasing economic and environmental pressures on the horticultural industry have prompted interest in sustainability over the past several years (Hall et al., 2009; Krug et al., 2008; Mattson et al., 2009). Sustainable horticultural practices have been described as methods that reduce environmental impact, conserve resources, support a stable community and high quality of life, and maintain economic viability (U.S. Government, 2007). Such practices include the proper use of supplemental lighting and efficient irrigation in greenhouses to optimize energy and water use. Understanding the precise light and water

Received for publication 6 Oct. 2011. Accepted for publication 2 Dec. 2011 Maine Agriculture and Forestry Experiment Station Publication \#3252.

We thank the Fred C. Gloeckner Foundation, the Maine Agriculture Center, and the Maine Agriculture and Forestry Experiment Station for funding this research; Bluestone Perennials (Madison, $\mathrm{OH}$ ) for donating plant material; Conrad Fafard Inc. (Agawam, MA) for donating media; Donglin Zhang and Brad Libby for helpful suggestions on an early draft of this report; and Michelle Gagne-Labbe, Brad Libby, Ellen Fisher, Lyle Burnett, and Mike Munson for their advice and technical support. ${ }^{1}$ Corresponding author. E-mail: Katherine.garland@maine.edu. requirements of crops is the key to using supplemental lighting and water efficiently.

Insufficient light limits growth for many crops. Reduced light results in lower shoot biomass, reduced leaf and flower production, and a lower total leaf area in many species (Faust et al., 2005; Oh et al., 2009; Pennisi et al., 2005). Growers provide supplemental lighting to increase the total photosynthetically active radiation [PAR (400-700 nm)] a plant receives throughout a day, the sum of which is termed DLI. Increasing DLI can increase the growth rate of sun-adapted species, thus reducing the time it takes to produce a marketable crop (Faust, 2003; Fisher and Both, 2004). However, increasing DLI may not result in a more marketable, rapidly growing crop for shade-adapted species. Differences in light requirements exist among species and sometimes cultivars. For example, increasing DLI beyond $19 \mathrm{~mol} \cdot \mathrm{m}^{-2} \cdot \mathrm{d}^{-1}$ resulted in no further increases in dry weight of Begonia semperflorens-cultorum (wax begonia) and Impatiens walleriana (bedding impatiens) (Faust et al., 2005). Increasing the DLI beyond $11.5 \mathrm{~mol} \cdot \mathrm{m}^{-2} \cdot \mathrm{d}^{-1}$ yielded no additional increase in leaf count or number of flowers in the shade-adapted plant Cyclamen persicum (cyclamen) 
(Oh et al., 2009). Conversely, shoot dry weights of sun-adapted Zinnia elegans (bedding zinnia) and Tagetes erecta (african marigold) continued to increase as DLIs reached $43 \mathrm{~mol} \cdot \mathrm{m}^{-2} \cdot \mathrm{d}^{-1}$ (Faust et al., 2005).

Plant genotype determines the plasticity of the response to increased DLI (Lambers et al., 2008). When exposed to high light, the sun-adapted plant Phaseolus vulgaris (common bean) has a greater capacity to adjust allocation of nitrogen resources toward ribulose-1,5-bisphosphate carboxylase (rubisco) synthesis (a factor that can limit photosynthetic capacity at high light levels) compared with the shade-adapted plant Alocasia macrorrhizos (giant taro). Meanwhile, when both species are grown in shade, giant taro allocates more nitrogen proportionally toward chlorophyll development to increase light interception (thus increasing photosynthetic activity at low light levels) compared with the common bean (Seeman et al., 1987). Differences can even exist between cultivars. Miller et al. (2001) reported that two cultivars of Angelonia angustifolia (angelonia) had different quantum yields (micromoles of $\mathrm{CO}_{2}$ fixed per incident micromole photon) and light compensation points (LCP), which correlated with a faster growth rate in the more photosynthetically efficient cultivar.

To understand if it is beneficial to supply crops with additional light, it is necessary to grow plants under various DLIs while observing both physiological and morphological characteristics. If an irrigation system is not responsive to changes in substrate water status as a result of increased evaporative demand, water stress can occur in plants exposed to high light or, conversely, plants growing in low light may experience periods of excessive water supply (Burnett and van Iersel, 2012). Capacitance sensor automated irrigation systems (Nemali and van Iersel, 2006), which trigger an irrigation valve to open if $\theta$ is too low, maintain a stable $\theta$ despite differences in plant water use under various DLIs (van Iersel et al., 2010), thus eliminating the question of whether water stress plays a role in studies assessing plant response to light.

There are many other benefits to such innovative irrigation technology, including the minimization of water consumption and elimination of effluent that could contain environmentally damaging nitrates and phosphates (Burnett and van Iersel, 2008; Nemali and van Iersel, 2006; Pierzynski et al., 2005). A study comparing the efficiency of this irrigation method with cyclic irrigation regulated by timers revealed that, over the course of a month, cyclic irrigation used 30 times more water than the system based on $\theta$ (Ristvey and Lea-Cox, 2008).

If capacitance sensor automated irrigation is to be used on a broad scale, it is important to know how plants respond to $\theta$ maintained at a steady, low level. Plant response to reduced water availability varies depending on the frequency, duration, and intensity of the stress imposed (Kramer and Boyer, 1995; Pospísilová and Dodd, 2005). However, most previous studies have exposed plants to brief, severe drought. For example, Eakes et al. (1991) allowed plants to dry down to visible wilt before rehydration, and Zollinger et al. (2006) watered plants once every 2 or 4 weeks to simulate drought. Investigators in other experiments refrained from watering until containers reached a certain target weight (Niu et al., 2006; Sánchez-Blanco et al., 2009; Starman and Lombardini, 2006). Although these investigations provide key insights into how certain crops respond to these specific types of water stress, their methods likely resulted in much greater fluctuations in $\theta$ compared with plants irrigated with more refined methods such as imposing $\theta$ treatments using a capacitance sensor automated irrigation system. Capacitance sensor automation can provide well-defined irrigation treatments that can be compared from one study to the next, which is an essential component to building a better understanding of the influence of water deficit on plant functions (Jones, 2007).

$\mathrm{WUE}_{\mathrm{c}}$ is a direct and valid means of assessing the efficiency in which a plant produces biomass relative to the amount of water applied and can be accurately measured using a capacitance sensor automated irrigation system that can monitor how much water is applied. Regulating irrigation in this manner may improve $\mathrm{WUE}_{\mathrm{c}}$ but can also reduce plant growth (Burnett and van Iersel, 2008). Therefore, it is important to understand both the physiological and morphological implications of producing plants under various $\theta$. Plants grown at low $\theta$ may have reduced leaf areas resulting from reduced meristem activity and/or insufficient turgor pressure for cell expansion (Lambers et al., 2008; van Volkenburgh, 1999). Although this may lower whole plant water loss by limiting evaporative surface area, it may also reduce whole plant photosynthesis and marketability of the crop (Franco et al., 2006). In some cases, stomatal conductance $\left(g_{\mathrm{S}}\right)$ may not fully recover after periods of sustained or periodic water stress or previously stressed plants may acclimate through increased sensitivity of stomata to abscisic acid, the primary hormone responsible for stomatal closure during water stress (Pospíšilová and Dodd, 2005). Even non-stomatal limitations to photosynthesis such as the maximum carboxylation rate of rubisco $\left(\mathrm{Vc}_{\max }\right)$ and the light saturated electron transport rate driving the regeneration of ribulose-1,5-bisphosphate $\left(\mathrm{J}_{\max }\right)$ can be influenced by reduced water availability (Flexas and Medrano, 2002). Instantaneous measures of $\mathrm{WUE}_{1}$ are commonly used to assess WUE because it is easily determined using leaf gas exchange measurements (Long and Bernacchi. 2003; Singh and Reddy, 2011; Starman and Lombardini, 2006; Zollinger et al., 2006). Because these measurements are generally taken on a part of a single leaf, $\mathrm{WUE}_{1}$ may not accurately reflect whole plant physiological responses.

Heuchera americana is an evergreen herbaceous perennial native to rocky, dry, deciduous understory habitats ranging from Ontario to Louisiana and Nebraska to Connecticut (Skillman and Osmond, 1998; U.S. Department of Agriculture, 2009). Although daylength becomes shorter in the winter, understory plants are often exposed to DLIs three to 10 times higher than those observed in the summer as a result of an open canopy. Despite freezing temperatures, photosynthetic capacity increases during winter high light periods without any sign of photoinhibition (Skillman et al., 1996). To our knowledge, net photosynthetic rate and estimates of photosynthetic capacity (other than chlorophyll fluorescence) have not been determined for american alumroot growing under DLIs higher than those observed in its native habitat. These estimations would be helpful indicators of appropriate DLIs for growing this crop in a greenhouse for commercial sales. Also, there is little more than anecdotal information regarding the specific water requirements of american alumroot (Cullina, 2000; Heims and Ware, 2005). Therefore, the objectives of this investigation were to: 1 ) determine the optimal $\theta$ set point for american alumroot production; 2) determine whether capacitance sensor regulated deficit irrigation has an impact on stomatal and non-stomatal limitations to photosynthesis; 3) explore whether american alumroot has the physiological capacity to acclimate to DLIs higher than those experienced in its native habitat; and 4) quantify and compare the long-term, whole-plant and instantaneous, leaf-level WUE of american alumroot under differing water and light availability. 


\section{Materials and Methods}

EXPT. 1: WATER. The first study began on 5 May 2008 and continued for $56 \mathrm{~d}$. Pre-vernalized $H$. americana 'Dale's Strain' young plants (plug size $6.0 \times 5.6 \times 7.0 \mathrm{~cm}$ ) were obtained from a commercial nursery (Bluestone Perennials, Madison, $\mathrm{OH})$. Young plants were transplanted into 3.8-L containers filled with $2.8 \mathrm{~L}$ of a commercial substrate $(60 \%$ peat: $40 \%$ perlite $(\mathrm{v} / \mathrm{v})$; Fafard 2P; Conrad Fafard, Agawam, MA). All containers were irrigated to container capacity immediately after planting and were subsequently watered with a continuous liquid feed solution containing $200 \mathrm{mg} \cdot \mathrm{L}^{-1}$ nitrogen $(\mathrm{N})(15 \mathrm{~N}-2.2 \mathrm{P}-12.45 \mathrm{~K}$; Peters EXCEL 15-5-15 Cal-Mag; Scotts, Marysville, OH). Beginning 10 June 2008, the fertilizer solution was changed so that $100 \mathrm{mg} \cdot \mathrm{L}^{-1} \mathrm{~N}$ was provided using the previously mentioned commercial fertilizer and another $100 \mathrm{mg} \cdot \mathrm{L}^{-1} \mathrm{~N}$ was applied in the form of $\mathrm{CaNO}_{3}$ as a result of low levels of calcium present in irrigation water.

Plants were irrigated using a capacitance sensor automated irrigation system, similar to that described in Nemali and van Iersel (2006), which maintained a constant substrate volumetric water content $(\theta)$ at one of eight set points $(\theta=0.15,0.2,0.25$, $0.3,0.35,0.4,0.45$, or $\left.0.5 \mathrm{~L} \cdot \mathrm{L}^{-1}\right)$. In this system, a data logger (CR-10X; Campbell Scientific, Logan, UT) measured the voltage output from the capacitance sensors (EC-5; Decagon Devices, Pullman, WA) every $5 \mathrm{~min}$. The data logger then calculated $\theta$ using a substrate-specific calibration equation $(\theta=$ voltage $\left.\times 1.7647-0.4745, r^{2}=0.95\right)$. The data logger switched on a relay driver (SDM-CD16AC; Campbell Scientific) to open a solenoid valve $(2.5 \mathrm{~cm}, 24 \mathrm{VAC}$ solenoid valves; Nelson Turf, Peoria, IL) for $20 \mathrm{~s}$ if the $\theta$ of the specific container was below the $\theta$ set point. When solenoid valves opened, plants were irrigated using pressure-compensated dribble rings (internal diameter $\approx 13 \mathrm{~cm}$; Dramm, Manitowoc, WI). The volume of water discharged from each emitter within each line was measured before the experiment at least three times. Emitters were replaced until outputs were uniform within each line. Lines emitted $72.9 \mathrm{~mL}( \pm$ $1.37 \mathrm{SE}$ ) during a single 20-s irrigation event. The total number of irrigation events was recorded by the data logger and later multiplied by the average emitter output for each individual line to determine the total volume of water applied to each plant over the entire investigation. Leaching did not occur.

Supplemental lighting was provided by $600-\mathrm{W}$ high-pressure sodium lights (PL2000; P.L. Light Systems, Beamsville, Ontario, Canada) from 0800 to $2000 \mathrm{HR}$. Light was monitored using quantum sensors (Model QSO-S; Apogee Instruments, Logan, UT) connected to the data logger, which measured $P A R$ every $20 \mathrm{~s}$. The data logger averaged the $P A R$ readings every 5 min throughout the entire investigation. DLI was calculated by using the mean of the 5-min PAR averages in the following equation: $P A R\left(\mu \mathrm{mol} \cdot \mathrm{m}^{-2} \cdot \mathrm{s}^{-1}\right) \times 86,400 \mathrm{~s} \cdot \mathrm{d}^{-1} / 10^{6} \mu \mathrm{mol} \cdot \mathrm{mol}^{-1}$.

Leaf gas exchange was evaluated during the final week of the study using a portable open-flow photosynthesis system (LI-6400; LI-COR, Lincoln, NE) equipped with a red/blue light-emitting diode light source. Unless otherwise noted, all measures were performed on the uppermost fully expanded leaf of a representative plant from each experimental unit. Linear and non-linear estimates of photosynthetic parameters were obtained using SYSTAT (Version 12; SYSTAT Software, Evanston, IL).

Response curves tracking the rate of net photosynthesis $\left(A_{N}\right)$ in response to internal leaf carbon dioxide concentrations $(\mathrm{Ci})$ were developed for one block of plants by exposing leaves to the following carbon dioxide concentrations: 400, 300, 250, $200,150,100,50,40,350,450,600,700,800,900,1000$, and $1200 \mu \mathrm{mol} \cdot \mathrm{mol}^{-1}$ allowing for ample time for $\mathrm{A}_{\mathrm{N}}$ to reach steady state within the leaf chamber. $P A R$ was maintained at saturating levels (400-480 $\mu \mathrm{mol} \cdot \mathrm{m}^{-2} \cdot \mathrm{s}^{-1}$ ) (Skillman and Osmond, 1998), mean leaf temperature was $21.5^{\circ} \mathrm{C}$, and relative humidity within the leaf cuvette was manually maintained at $\approx 65 \%$ to $70 \%$, resulting in a vapor pressure deficit of $\approx 0.85 \mathrm{kPa}$.

Respiration and the maximum carboxylation rate of rubisco $\left(\mathrm{Vc}_{\max }\right)$ were estimated from a regression line fitted to the initial linear part of the $A_{N}-C_{i}$ response curve $\left(C_{i}\right.$ less than 400 $\left.\mu \mathrm{mol} \cdot \mathrm{m}^{-2} \cdot \mathrm{s}^{-1}\right)$. Mitochondrial respiration rate in the light $\left(\mathrm{R}_{1}\right)$ was estimated to be the point where the regression line crossed the $\mathrm{Y}$-axis and $\mathrm{Vc}_{\max }$ was estimated using the following model: $A_{N}=C_{i} \times V c_{\text {max }}-R_{d}$ where $C_{i}$ is the concentration of $C_{2}$ within the leaf and $\mathrm{A}_{\mathrm{N}}$ represents the net rate of photosynthesis (Long and Bernacchi, 2003).

$\mathrm{J}_{\max }$, the light saturated electron transport rate driving the regeneration of ribulose-1,5-bisphosphate, was estimated using the latter part of the $A_{N}-C_{i}$ response curve $\left(C_{i}=400-900\right.$ $\left.\mu \mathrm{mol} \cdot \mathrm{m}^{-2} \cdot \mathrm{s}^{-1}\right)$ with the following model: $A_{N}=g^{\prime} \times J_{\max }-R_{d}$ where $\mathrm{g}^{\prime}$ is obtained from the following calculation: $g^{\prime}=\left(C i-\Gamma^{*}\right) /\left(4.5 \times C i+10.5 \Gamma^{*}\right)$. $\Gamma^{*}$ represents the photosynthetic $\mathrm{CO}_{2}$ compensation point at the chloroplast, estimated to be $37 \mu \mathrm{mol} \cdot \mathrm{mol}^{-1}$ (Bernacchi et al., 2002; Long and Bernacchi, 2003).

Whole-canopy $\mathrm{WUE}_{\mathrm{c}}$ was calculated by dividing the shoot dry weight at harvest by the total water applied. Water applied was calculated with the following equation:

$$
(\mathbf{I} \times \mathbf{W})+\left[\left(\theta_{\mathrm{I}}-\theta_{\mathrm{SP}}\right) \times 2.8 \mathrm{~L}\right]
$$

The variable I represents the number of irrigation events, $\mathrm{W}$ is the volume of water applied during each irrigation event, $\theta_{\mathrm{I}}$ is the initial $\theta, \theta_{\mathrm{SP}}$ is the $\theta$ set point, and $2.8 \mathrm{~L}$ is the volume of substrate in the container. Instantaneous measures of $\mathrm{A}_{\mathrm{N}}$ and $g_{\mathrm{S}}$ were used to calculate $\mathrm{WUE}_{1}$. Values were obtained at $\mathrm{CO}_{2}$ levels of $400 \mu \mathrm{mol} \cdot \mathrm{mol}^{-1}$ and saturating $P A R$.

Crown width at the widest point and petiole length of the uppermost fully expanded leaf were measured weekly throughout the entire investigation. On the final day of the experiment, the total number of leaves on all plants was counted and total leaf area was measured on one representative plant from each experimental unit using a leaf area meter (LI-3100A; LI-COR). Shoot tissue was dried for at least 1 month in a room used for drying soil and plant samples. Here exposed steam pipes maintain temperature at $\approx 50{ }^{\circ} \mathrm{C}$. Dry mass was later recorded. American alumroot shoot dry mass includes only leaf tissue because the stem is a small crown, which was not harvested. Leaf area ratio (LAR) was calculated as leaf area/shoot dry mass.

The experimental design was a randomized complete block design with two blocks for each treatment. In each experimental unit, there were three subsamples (each subsample was a single plant in a container) for a total of six plants for each $\theta$ set point. Within each block, a capacitance sensor was inserted horizontally $3 \mathrm{~cm}$ below the substrate in one of the three containers. Measurements from this sensor were used to control irrigation in that container (Nemali and van Iersel, 2006) and two neighboring containers. All data were analyzed using regression analysis and Fisher's protected least significant difference (LSD) means separation using SAS (Version 9.1; SAS Institute, Cary, NC). 
Probability values less than or equal to 0.05 were considered statistically significant.

ExPт. 2: Light. The light investigation ran for $45 \mathrm{~d}$ beginning 19 May 2008. Plant material and initial cultural methods (i.e., transplanting, initial watering, and fertilizer application) for this study were as described in Expt. 1. Supplemental lighting described in Expt. 1 was also used to increase DLIs for all treatments.

Plants were covered with nothing or a single, double, or triple layer of commercial 30\% shadecloth (K-Pro Supply, Sarasota, FL), which resulted in average DLIs of 21.8, 14.9, 10.8 , and $7.5 \mathrm{~mol} \cdot \mathrm{m}^{-2} \cdot \mathrm{d}^{-1}$, respectively. Shadecloth was provided on all sides of plants for the three lowest DLIs by covering square $(0.6 \times 0.6 \times 0.6 \mathrm{~m})$ polylvinyl chloride $(\mathrm{PVC})$ pipe structures with shadecloth. Light levels were monitored under each shade structure or portion of exposed bench (for non-shaded plants) using a quantum sensor set up in the same manner as those used in the water deficit experiment. $\theta$ was maintained at $0.35 \mathrm{~L} \cdot \mathrm{L}^{-1}$ for plants grown under all DLIs using the capacitance sensor automated irrigation system described previously. Shaded type T thermocouples were connected to the data logger to continuously monitor temperature under each shade structure or exposed portion of bench. Shade structures did not significantly impact temperature, but location in proximity to the pad-and-fan cooling system did affect temperature. There was a gradient in temperature so that all temperatures were cooler close to the cellulose pad used for cooling and warmer on benches closer to the exhaust fan. This gradient is typical in greenhouses cooled using a pad-and-fan cooling system (Nelson, 2003). However, the use of blocks was intended to reduce the impact of these gradients on treatment differences.

Instantaneous $\mathrm{A}_{\mathrm{N}}$ and $g_{\mathrm{S}}$ measures were collected from one representative plant in each experimental unit as described previously. In addition, $\mathrm{A}_{\mathrm{N}}-\mathrm{Ci}$ curves were measured in the high light and low light treatments only. Methods for collecting gas exchange measurements and calculating photosynthetic parameter estimates are as described previously. $\mathrm{WUE}_{1}$ and $\mathrm{WUE}_{\mathrm{c}}$ were calculated as described previously.

Light response $\left(\mathrm{A}_{\mathrm{N}}-\mathrm{Q}\right)$ curves were developed using one representative plant from each experimental unit. Using a light-emitting diode light source, leaves were exposed to the following incremental levels of PAR: 2000, 1500, 1000, 500, 200, $100,50,20$, and $0 \mu \mathrm{mol} \cdot \mathrm{m}^{-2} \cdot \mathrm{s}^{-1} \mathrm{pro}-$ viding ample time for photosynthesis to approach equilibrium. $\mathrm{CO}_{2}$ concentration within the leaf chamber was kept at $400 \mu \mathrm{mol} \cdot \mathrm{mol}^{-1}$, mean leaf temperature was $23.4{ }^{\circ} \mathrm{C}$, and relative humidity remained $\approx 65 \%$ to $70 \%$, resulting in a vapor pressure deficit of $\approx 0.85 \mathrm{kPa}$.
Dark respiration $\left(\mathrm{R}_{\mathrm{d}}\right)$ was estimated using linear regression from the initial part of the light response curve where the $P A R$ was below $90 \mu \mathrm{mol} \cdot \mathrm{m}^{-2} \cdot \mathrm{s}^{-1}$. Quantum efficiency $(Q E)$ and the maximum rate of $A_{N}\left(A_{N \text { max }}\right)$ were estimated by fitting data to a non-rectangular hyperbola (Prioul and Chartier, 1977).

The LCP was calculated as the point where the linear portion of the light response curve crosses the $\mathrm{x}$ axis (where $\mathrm{A}_{\mathrm{N}}=0$ ) using values determined for respiration (y intercept) and quantum efficiency (slope) in the slope intercept equation: $0=Q E \times$ $\mathrm{LCP}+\mathrm{R}_{\mathrm{d}}$.

A handheld chlorophyll meter (SPAD 502; Minolta, Ramsey, NJ) was used to non-destructively evaluate relative chlorophyll concentration in plants from the light investigation. This measurement was taken twice, $31 \mathrm{~d}$ after transplanting (DAT) and 43 DAT on three different portions of the uppermost fully expanded leaf of each plant. These three measurements were averaged. American alumroot foliage is basal; therefore, the uppermost fully expanded leaf was considered to be the highest held fully expanded leaf located nearest to the center of the crown. Care was taken to measure the area between leaf veins, because the vein tissue is typically darker green or purple compared with the rest of the leaf tissue.

Weekly measurements of canopy width and petiole length and measurements of final leaf area, leaf count, dry weight, water applied, and LAR were collected using the same methods
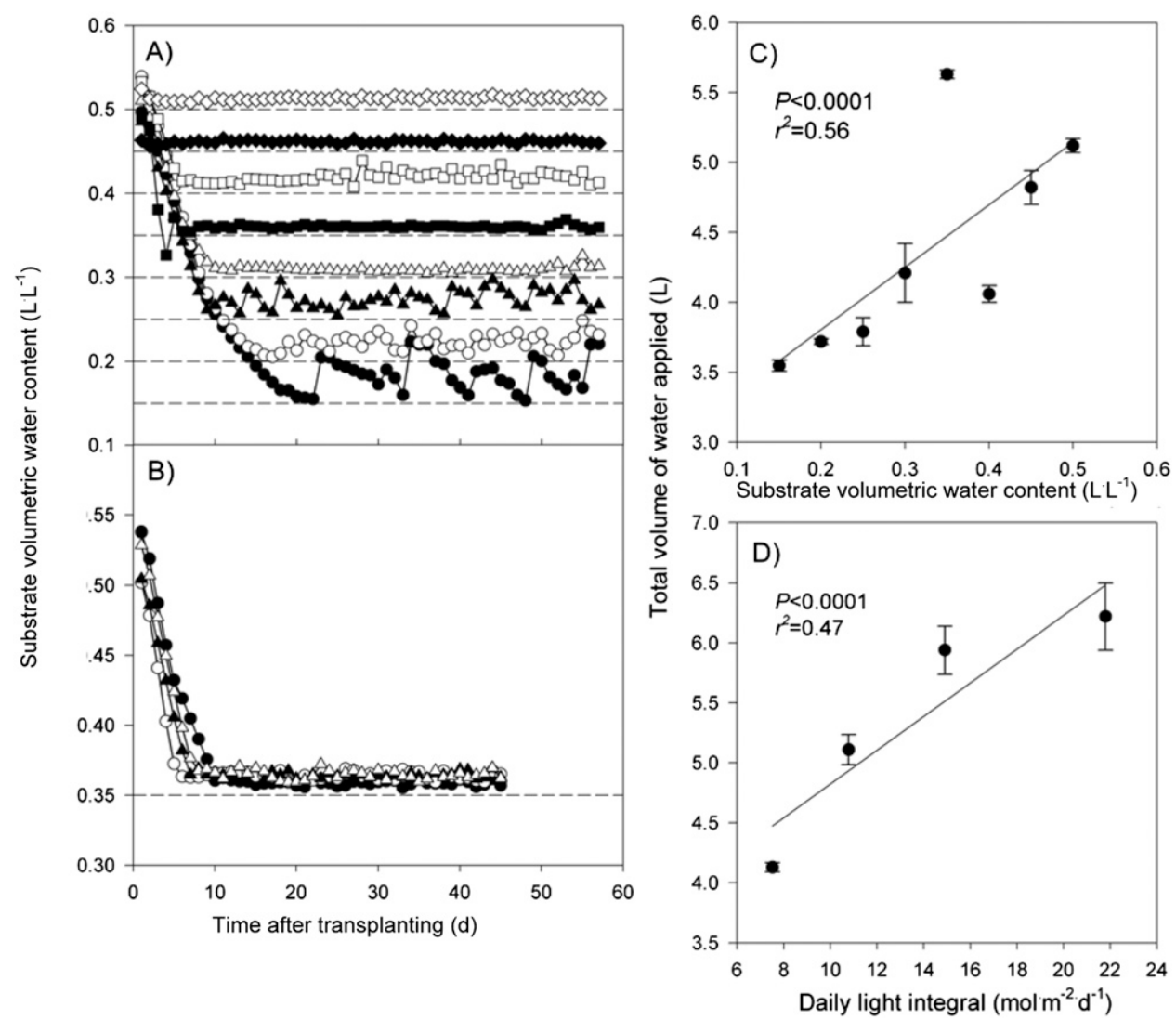

Fig. 1. Daily average substrate volumetric water content $(\theta)$ over time during the $\theta$ study $(\mathbf{A})$ and the light study (B) and total volume of water applied per plant to Heuchera americana 'Dale's Strain' over the entire course of the $\theta$ study $(\mathbf{C})$ and the light study (D). In (A), the symbols $\diamond, \bullet, \square, \mathbf{\square}, \Delta, \boldsymbol{\Delta}, \bigcirc$, and $\bigcirc$ represent the $\theta$ set points 0.5 , $0.45,0.4,0.35,0.3,0.25,0.2$, and $0.15 \mathrm{~L} \cdot \mathrm{L}^{-1}$, respectively. In $(\mathbf{B})$, the symbols $\Delta, \mathbf{\Delta}, \bigcirc$, and $\bigcirc$ represent the daily light integrals $21.8,14.9,10.8$, and $7.5 \mathrm{~mol} \cdot \mathrm{m}^{-2} \cdot \mathrm{d}^{-1}$, respectively. Dashed lines indicate irrigation set points. Data in $\mathbf{A}$ and $\mathbf{B}$ represent mean of two and four replications respectively where $\theta$ was measured every 5 min over the entire investigation. Data in $\mathbf{C}$ and $\mathbf{D}$ represent mean of two replications. Error bars in all figures represent the SE. 
described in the water study. Lines emitted $76.9 \mathrm{~mL}( \pm 2.1 \mathrm{SE})$ during a single 20 -s irrigation event.

The experimental design was randomized complete block design with four blocks. An experimental unit consisted of four plants (subsamples) under one shade structure or for nonshaded plants sitting on the greenhouse bench. There were a total of 16 plants for each DLI. All data were analyzed using regression analysis and Fisher's LSD means separation using SAS (Version 9.1). Probability values less than or equal to 0.05 were considered statistically significant.

\section{Results and Discussion}

$\theta$ AND VOLUME OF WATER APPLIED. After the substrates dried to their respective treatment levels, $\theta$ was maintained close to all set points throughout the remainder of both investigations (Fig. 1A-B). The total volume of water applied throughout the irrigation experiment increased linearly with increasing $\theta$ set point (Fig. 1C). Mean values for applied water ranged from 3.6 to $5.6 \mathrm{~L} /$ plant in substrates maintained at a $\theta$ of $0.15 \mathrm{~L} \cdot \mathrm{L}^{-1}$ and $0.35 \mathrm{~L} \cdot \mathrm{L}^{-1}$, respectively. Greater fluctuations in $\theta$ observed in the drier treatments may have been the result of lower hydraulic conductivity slowing water movement through the substrate (Naasz et al., 2005). Analogous fluctuations have been observed in similar studies (Burnett and van Iersel, 2008; Nemali and van Iersel, 2006; van Iersel et al., 2010).

Total volume of water applied increased with increasing DLI with mean values ranging from $4.1 \mathrm{~L}$ in the lowest DLI to $6.2 \mathrm{~L} /$ plant in the highest DLI (Fig. 1D). This corroborates the findings of van Iersel et al. (2010), who observed that daily fluctuations in irrigation demand were strongly correlated with DLI. Kim et al. (2011) found that DLI was the most important environmental factor in predicting plant water use and proposed a model for predicting daily water use in greenhouse settings based on plant age and DLI. In that study, other environmental factors such as temperature and vapor pressure deficit improved the model fit less than DLI.

EXPT. 1: WATER. Plants grown at all $\theta$ set points survived and were considered marketable, although plants grown in drier substrates were smaller than those irrigated at higher $\theta$ set points. Shoot dry weight was positively correlated with $\theta$ set point
(Fig. 2A). Mean DLI and temperature were $22.0 \mathrm{~mol} \cdot \mathrm{m}^{-2} \cdot \mathrm{d}^{-1}$ and $19.8^{\circ} \mathrm{C}$, respectively. Plants grown in substrates irrigated at the lowest set point $\left(0.15 \mathrm{~L} \cdot \mathrm{L}^{-1}\right)$ weighed $7.63 \mathrm{~g}$, whereas plants grown in substrates irrigated at the highest set point $\left(0.5 \mathrm{~L} \cdot \mathrm{L}^{-1}\right)$ were $9.75 \mathrm{~g}$. A correlation between shoot dry weight and $\theta$ set point has also been noted in a number of other ornamental crops including Gaura lindheimeri (gaura), Abutilon xhybridum (abutilon), and Lantana camara (lantana) (Burnett and van Iersel, 2008; Kim and van Iersel, 2009). Until recently, it was thought that peat-based substrates had little to no plant-available water when $\theta$ is below $0.20-0.24 \mathrm{~L} \cdot \mathrm{L}^{-1}$ (Wallach, 2008). This observation supports the concerns of
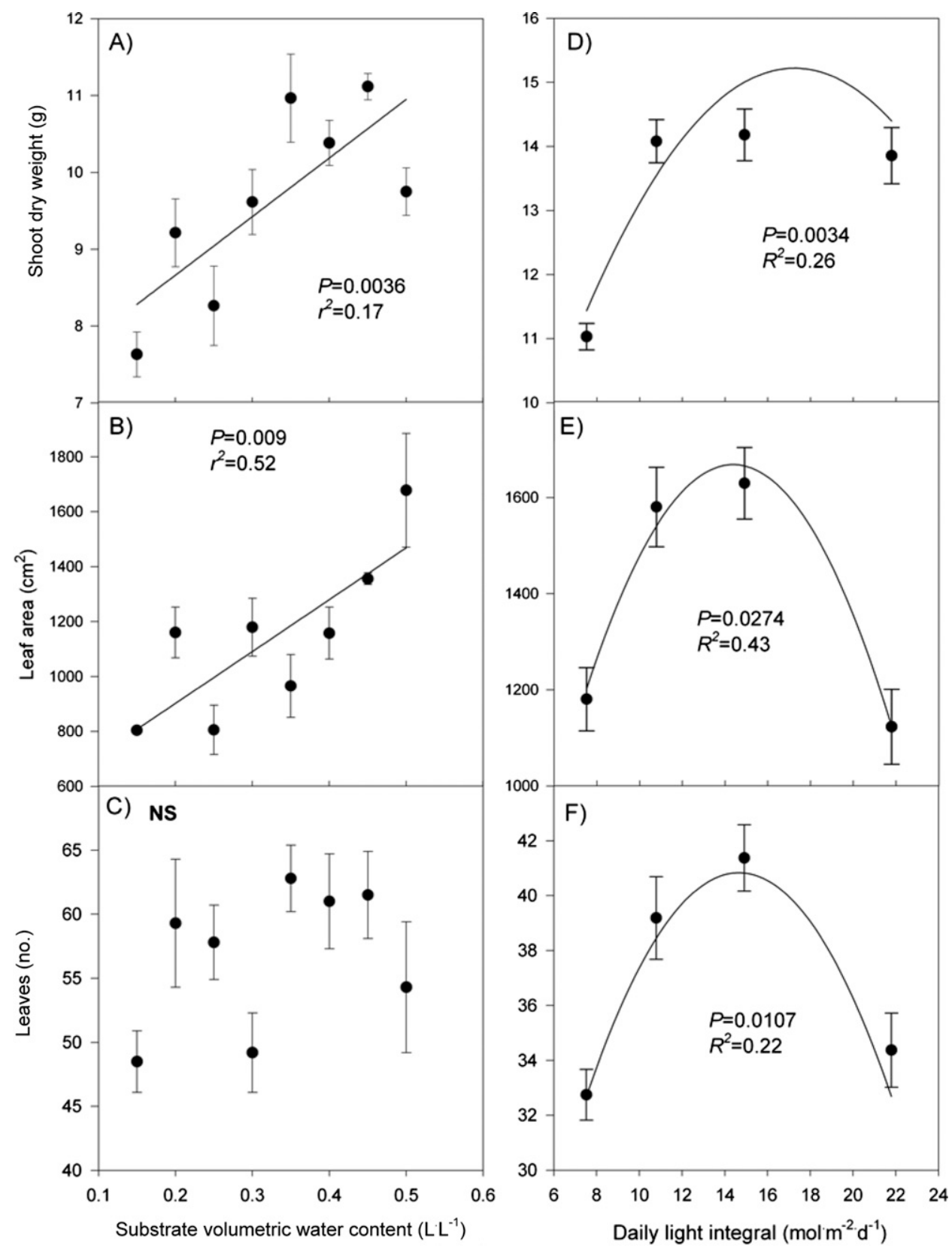

Fig. 2. The influence of substrate volumetric water content $(\theta)(\mathbf{A}-\mathbf{C})$ and daily light integral (DLI) (D-F) on shoot dry weight (A and $\mathbf{D})$, total leaf area (B and $\mathbf{E})$, and total number of leaves $(\mathbf{C}$ and $\mathbf{F})$ produced on the ornamental plant Heuchera americana 'Dale's Strain'. Data in $\mathbf{A}$ and $\mathbf{C}$ represent the means of six replications, $\mathbf{D}$ and $\mathbf{F}$ represent means of 16 replications, $\mathbf{B}$ represents the means of two replications, and $\mathbf{E}$ represents the means of four replications with error bars representing the SE. NS indicates the data are non-significant. 
others questioning the reliability of substrate water release curves alone to predict plant-available water (van Iersel et al., 2010).

Total leaf area was positively correlated with $\theta$ (Fig. 2B). Leaf area of plants growing at the highest set point was about double $\left(\right.$ mean $\left.=1678 \mathrm{~cm}^{2}\right)$ that observed at the lowest set point $\left(804 \mathrm{~cm}^{2}\right)$. These differences in total leaf area were the result of a tendency toward higher leaf count and larger leaves, although neither of these effects was significant by themselves (Fig. 2C). Water availability may limit leaf size by reducing meristem activity or the turgor required for cell wall expansion (Lambers et al., 2008; van Volkenburgh, 1999). Pelargonium $\times$ hortorum (bedding geranium) and Plumbago auriculata (plumbago) are examples of other ornamental crops that have smaller shoot dry weights and leaf areas when exposed to water deficits (Niu et al., 2006; Sánchez-Blanco et al., 2009). Reduced leaf area in response to lower water availability has been reported in a number of other studies as well (Burnett et al., 2005; Starman and Lombardini, 2006; Zollinger et al., 2006). Weekly and final measures of plant width did not differ among $\theta$ set points (data not shown). At the end of the experiment, width of american alumroot averaged $28.0 \mathrm{~cm}$.

Although total leaf area was positively correlated with $\theta, A_{N}$ and $g_{\mathrm{S}}$ per unit area did not differ among treatments (Table 1). Water stress commonly results in reduced stomatal aperture, which limits the diffusion of $\mathrm{CO}_{2}$ to the carboxylation site, thus slowing the rate of photosynthesis (Flexas et al., 2008; Kramer and Boyer, 1995). Although water stress can influence metabolic function (Flexas and Medrano, 2002), $\theta$ from 0.15 to 0.50 $\mathrm{L} \cdot \mathrm{L}^{-1}$ did not impact the non-stomatal components of photosynthesis $\left(\mathrm{Vc}_{\max }, \mathrm{J}_{\max }\right.$, and $\mathrm{R}_{\mathrm{d}}$ ) (Table 1). Our data suggest that stomatal and non-stomatal limitations to photosynthesis did not cause the observed changes in growth of american alumroot in response to $\theta$. Because we did not observe any effects on photosynthesis per unit leaf area, it seems plausible that differences in leaf area development were the underlying cause for the observed growth responses.

$\mathrm{A}_{\mathrm{N}}$ of Salvia splendens (annual salvia), Catharanthus roseus (annual vinca), petunia, and bedding impatiens also did not differ among $\theta$ ranging from 0.15 to $0.32 \mathrm{~L} \cdot \mathrm{L}^{-1}$ (Nemali and van Iersel, 2008). Conversely, $\mathrm{A}_{\mathrm{N}}$ of Eupatorium rugosum (eastern white snakeroot) and Rudbeckia triloba (three-lobed coneflower) was negatively impacted by $\theta$ (Prevete et al., 2000). Care should be taken when comparing plant responses to prolonged, regulated deficit irrigation (as in Nemali and van Iersel, 2008) with responses in plants exposed to short-term water deficits such as Prevete et al. (2000). Both types of water stress investigations may be valid, but they can be influenced by factors other than the current $\theta$ such as the degree to which the plants acclimated to drought (Jones, 2007).

$\mathrm{WUE}_{\mathrm{c}}$ showed a quadradic effect increasing with decreasing $\theta$ to $0.3 \mathrm{~L} \cdot \mathrm{L}^{-1}$ but decreased back with further decreasing $\theta$. (Fig. 3A). $\mathrm{WUE}_{\mathrm{c}}$ of gaura also increased with decreasing $\theta$ when plants were irrigated using similar methods (Burnett and van Iersel, 2008). $\mathrm{WUE}_{\mathrm{c}}$ may include water lost to inefficient irrigation practices, (i.e., leaching resulting from overwatering) resulting in lower efficiency values. However, leaching did not occur in this study, and the $\mathrm{WUE}_{\mathrm{c}}$ calculated here is indicative of the $\mathrm{WUE}_{\mathrm{c}}$ that can be achieved using very efficient irrigation practices.

Conversely, $\mathrm{WUE}_{1}$ was not influenced by $\theta$ (Fig. 3B). Although WUE $_{1}$ increased with decreasing $\theta$ in ornamental crops such as bedding impatiens, annual salvia, and annual vinca, it was unaffected in petunia (Nemali and van Iersel, 2008). WUE $E_{1}$ values observed here were similar to those of other bedding plants (Nemali and van Iersel, 2008). One difficulty in comparing these metrics of $\mathrm{WUE}_{1}$ results from transpiration rates being influenced not only by $g_{\mathrm{S}}$, but also by leaf-to-air vapor pressure deficit. In addition, the relationship between $\mathrm{WUE}_{1}$ and $\mathrm{WUE}_{\mathrm{c}}$ can be poor because of the many factors influencing dry matter accumulation that may not be reflected in instantaneous gas exchange measures (Kramer and Boyer, 1995). Factors impacting the apparent discrepancy in WUE values may include differences in dry matter allocation, dark respiration rates, changes in $g_{\mathrm{S}}$ throughout the day, and differences in $g_{\mathrm{S}}$ across a single leaf surface and differences in $g_{\mathrm{S}}$ among different leaves on the same plant (Kramer and Boyer, 1995). In addition, measurements of $\mathrm{WUE}_{1}$ are often taken under lightsaturating conditions, which are not indicative of the actual growing environment. Thus, care should be taken when extrapolating $\mathrm{WUE}_{1}$ measurements to predict whole plant water use efficiency.

Expt. 2: Light. Plants grown under the lowest light treatment had significantly lower shoot dry weight, but shoot dry weight did not differ among the three higher DLIs, indicating that american alumroot became saturated at $\approx 11 \mathrm{~mol} \cdot \mathrm{m}^{-2} \cdot \mathrm{d}^{-1}$ (Fig. 2D). DLI affected total leaf area in a quadratic manner (Fig. 2E) with the largest leaf areas at DLIs of 10.8 and $14.9 \mathrm{~mol} \cdot \mathrm{m}^{-2} \cdot \mathrm{d}^{-1}$. Reduced leaf area in plants grown at 21.8 $\mathrm{mol} \cdot \mathrm{m}^{-2} \cdot \mathrm{d}^{-1}$ was caused by a low number of leaves. Leaf count increased as DLI increased from 7.5 to $14.9 \mathrm{~mol} \cdot \mathrm{m}^{-2} \cdot \mathrm{d}^{-1}$ but decreased again as DLI further increased to 21.8 $\mathrm{mol} \cdot \mathrm{m}^{-2} \cdot \mathrm{d}^{-1}$ (Fig. 2F). Other crops with a relationship between leaf count and DLI include cyclamen and Adiantum raddianum 'Fritz Luth' (maidenhair fern) (Oh et al., 2009; Yeh and Wang, 2000). 
Lower leaf areas at the highest DLI did not correspond with a similar decrease in dry weight. LAR was negatively correlated with DLI, suggesting that the leaves grown at 21.8 $\mathrm{mol} \cdot \mathrm{m}^{-2} \cdot \mathrm{d}^{-1}$ were the thickest (Fig. 4). This change in leaf structure, an adaptation to higher light environments, has been previously reported in american alumroot (Skillman et al., 1996) as well as in many other species including Ageratum houstonianum (ageratum), wax begonia, bedding impatiens, african marigold, petunia, Salvia coccinea (scarlet sage), annual vinca, and bedding zinnia (Faust et al., 2005). Lower leaf area in the higher light treatments decreases the relative surface to mass ratio and may reduce the amount of water lost through transpiration (Yeh and Wang, 2000), resulting in more efficient use of absorbed radiation in high-light environments (Terashima and Hikosaka, 1995) and minimize damage to photosynthetic systems from excess light interception (Osmond, 1994).

Altering leaf orientation may also increase or decrease plant exposure to irradiance (Givnish, 1988). Shade-adapted species such as the herbaceous understory plant Adenocaulon bicolor (trail plant) modify leaf arrangement, petiole length, leaf angle, and leaf size to optimize light capture (Pearcy and Yang, 1998). American alumroot, which is native to understory habitats, plastically alters shoot morphology in response to DLI. At lower DLI, petiole length of the uppermost fully expanded leaf increased, allowing plants to reduce intraplant competition for light (Fig. 5A). Phytohormones play a key role in such plant responses to changing light conditions (Stamm and Kumar, 2010). At the highest DLI, plants exhibited a marked decrease in crown width (Fig. 5B). For american alumroot, width is a function of both petiole length and leaf area (Fig. 5C). Taken together, this indicates that american alumroot changes canopy architecture to optimize light capture under low DLI or increase intracanopy shading at high DLI. Height was not influenced by light environment in the investigation (data not shown).

American alumroot was able to survive DLIs up to 21.8 $\mathrm{mol} \cdot \mathrm{m}^{-2} \cdot \mathrm{d}^{-1}$ but exhibited no increase in shoot biomass above $10.8 \mathrm{~mol} \cdot \mathrm{m}^{-2} \cdot \mathrm{d}^{-1}$. Net photosynthetic rates did not differ among light treatments nor did estimates of carboxylation $\left(\mathrm{Vc}_{\max }\right)$ and electron transport $\left(\mathrm{J}_{\max }\right)$ rates (Table 2), indicators of biochemical investment in photosynthetic capacity. Light-saturated photosynthetic rates (Table 2) were not significantly different at any level.

Previous studies demonstrated that american alumroot possesses the capacity to acclimate to seasonal changes in light as well as changes imposed in the laboratory (Skillman et al., 1996; Skillman and Osmond, 1998). DLIs commonly experienced by american alumroot in its native habitat range from

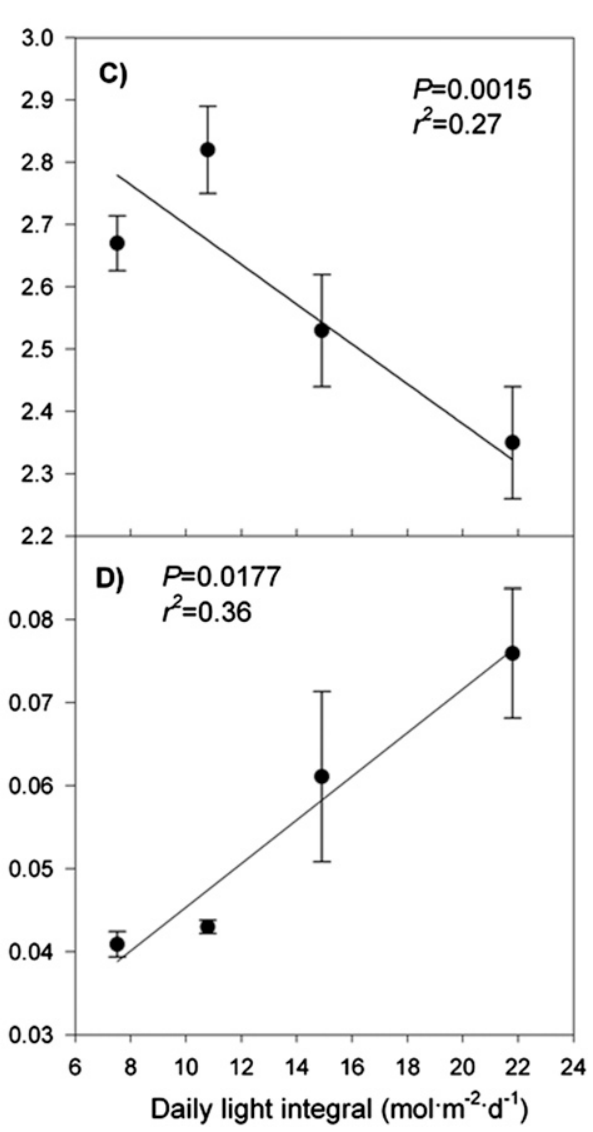

Fig. 3. The influence of substrate volumetric water content $(\theta)$ (A-B) and daily light integral (DLI) (C-D) on whole crop water use efficiency $\left(W_{U}\right)(\mathbf{A}$ and $\mathbf{C})$ and leaf level water use efficiency in terms of the rate of net photosynthesis volume of water emitted (L) during each irrigation event). $\mathrm{WUE}_{1}$ values were obtained from instantaneous gas exchange measures. Data points in $\mathbf{A}$ and $\mathbf{B}$ represent the mean of eight and two replications, respectively. In $\mathbf{C}$ and $\mathbf{D}$, points represent the mean of 16 and four replications, respectively. Bars in all figures represent the SE. Data points in B without SE bars represent single replication due to measurement error. NS indicates the data are non-significant.

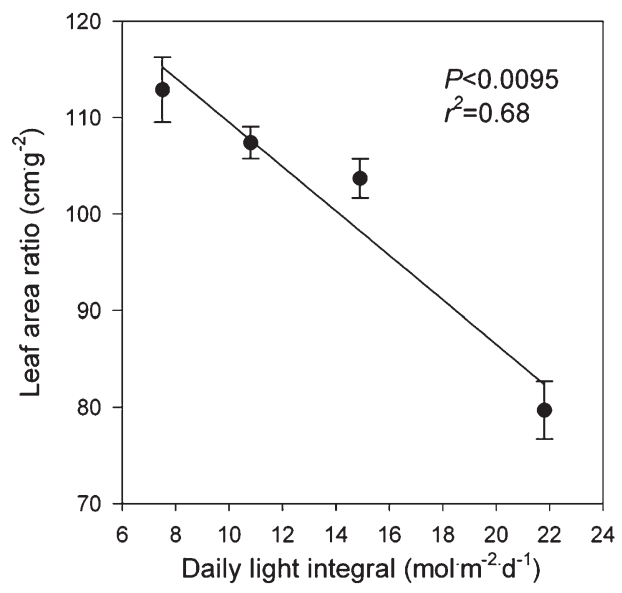

Fig. 4. The effect of daily light integral on leaf area ratio of Heuchera americana 'Dale's Strain'. Data represent the mean of four replications with error bars representing the SE.

$\approx 1 \mathrm{~mol} \cdot \mathrm{m}^{-2} \cdot \mathrm{d}^{-1}$ in the summer, when the tree canopy above has closed, to roughly $11 \mathrm{~mol} \cdot \mathrm{m}^{-2} \cdot \mathrm{d}^{-1}$ in the winter, after trees have dropped their leaves (Skillman et al., 1996). The three highest treatments applied in this investigation $(10.8,14.9$, and 

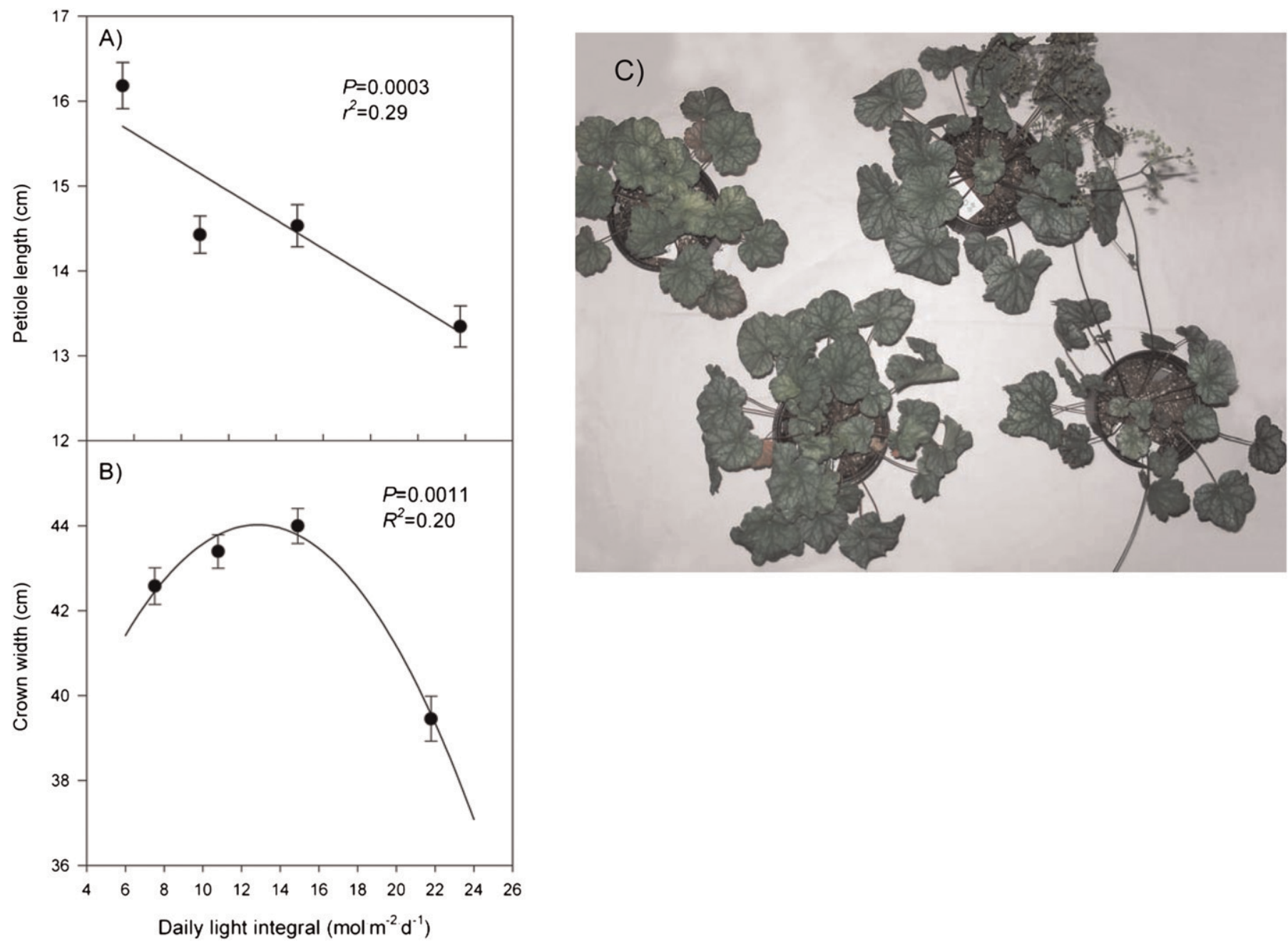

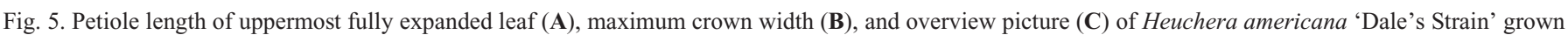
under four daily light integrals for $45 \mathrm{~d}$. Data represent the mean of four replications with error bars representing the sE.

Table 2. Net photosynthesis $\left(\mathrm{A}_{\mathrm{N}}\right)$, quantum efficiency $(Q E)$, light compensation point (LCP), maximum photosynthetic capacity $\left(\mathrm{A}_{\mathrm{N}}\right.$ max $)$, dark respiration $\left(\mathrm{R}_{\mathrm{d}}\right)$, and maximum carboxylation rate $\left(\mathrm{Vc}_{\max }\right)$ of Heuchera americana 'Dale's Strain' exposed to one of four daily light integrals for a period of $45 \mathrm{~d}^{\mathrm{z}}$

\begin{tabular}{|c|c|c|c|c|c|c|}
\hline $\begin{array}{l}\text { Daily light } \\
\text { integral }\end{array}$ & $\begin{array}{c}\mathrm{A}_{\mathrm{N}} \\
\left(\mu \mathrm{mol} \cdot \mathrm{m}^{-2} \cdot \mathrm{s}^{-1}\right)\end{array}$ & $\begin{array}{c}Q E \\
\left(\mathrm{mmol} \cdot \mathrm{mol}^{-1}\right)\end{array}$ & $\begin{array}{c}\text { LCP } \\
\left(\mu \mathrm{mol} \cdot \mathrm{m}^{-2} \cdot \mathrm{s}^{-1}\right)\end{array}$ & $\begin{array}{c}\mathrm{A}_{\mathrm{N} \max } \\
\left(\mu \mathrm{mol} \cdot \mathrm{m}^{-2} \cdot \mathrm{s}^{-1}\right)\end{array}$ & $\begin{array}{c}\mathrm{R}_{\mathrm{d}} \\
\left(\mu \mathrm{mol} \cdot \mathrm{m}^{-2} \cdot \mathrm{s}^{-1}\right)\end{array}$ & $\begin{array}{c}\mathrm{Vc}_{\max } \\
\left(\mu \mathrm{mol} \cdot \mathrm{m}^{-2} \cdot \mathrm{s}^{-1}\right)\end{array}$ \\
\hline$\left(\mathrm{mol} \cdot \mathrm{m}^{-2} \cdot \mathrm{d}^{-1}\right)$ & \multicolumn{6}{|c|}{ Mean $\pm \mathrm{SE}$} \\
\hline 7.5 & $9.71 \mathrm{a} \pm 0.30$ & $140 \mathrm{a} \pm 19$ & $3.47 \mathrm{a} \pm 0.73$ & $11.0 \mathrm{a} \pm 0.32$ & $0.45 \mathrm{a} \pm 0.10$ & $19.3 \mathrm{a} \pm 0.39$ \\
\hline 14.9 & $9.47 \mathrm{a} \pm 0.51$ & $134 \mathrm{a} \pm 9$ & $4.71 \mathrm{a} \pm 0.66$ & $10.6 \mathrm{a} \pm 0.62$ & $0.66 \mathrm{a} \pm 0.11$ & - \\
\hline 21.8 & $9.11 \mathrm{a} \pm 0.49$ & $120 \mathrm{a} \pm 12$ & $4.96 \mathrm{a} \pm 1.08$ & $10.0 \mathrm{a} \pm 0.78$ & $0.58 \mathrm{a} \pm 0.13$ & $20.8 \mathrm{a} \pm 0.86$ \\
\hline
\end{tabular}

${ }^{\mathrm{z}} \mathrm{A}_{\mathrm{N}}$ data are from instantaneous measurements; $Q E, \mathrm{LCP}, \mathrm{A}_{\mathrm{N} \text { max }}$, and $\mathrm{R}_{\mathrm{d}}$ data are from $\mathrm{A}_{\mathrm{N}}-\mathrm{Q}$ curves; $\mathrm{Vc}_{\max }$ data are derived from $\mathrm{A}_{\mathrm{N}}-\mathrm{C}_{\mathrm{i}}$ curves.

$\left.21.8 \mathrm{~mol} \cdot \mathrm{m}^{-2} \cdot \mathrm{d}^{-1}\right)$ were toward the top of or above the range of DLI observed in native sites. Light response curves (Fig. 6A) and carbon dioxide response curves (Fig. 6B) indicate no acclimation to DLIs greater than those outside american alumroot's native habitat.

One possible explanation for the lack of photosynthetic acclimation to higher DLIs is associated with the relatively low growth rate of the species. Increasing light without a corresponding increase in carbohydrate sink strength can result in the accumulation of carbohydrates in the foliage, which can regulate photosynthetic capacity through epigenetic feedback mechanisms
(Paul and Foyer, 2001). Supporting this hypothesis is the observation that american alumroot shoot dry weight is highest at a DLI of $10.8 \mathrm{~mol} \cdot \mathrm{m}^{-2} \cdot \mathrm{d}^{-1}$ (Fig. 2D).

SPAD measurements, which correlate with chlorophyll concentration per leaf area, decreased with increasing DLI (Fig. 7). This is an expected physiological attribute of shade adaptation, and other researchers have observed that chlorophyll concentration increases in plants exposed to lower light levels for a number of species (Nemali and van Iersel, 2004, Rothstein and Zak, 2001; Skillman et al., 1996). This adaptive trait generally enhances the light-capturing capacity of plants 

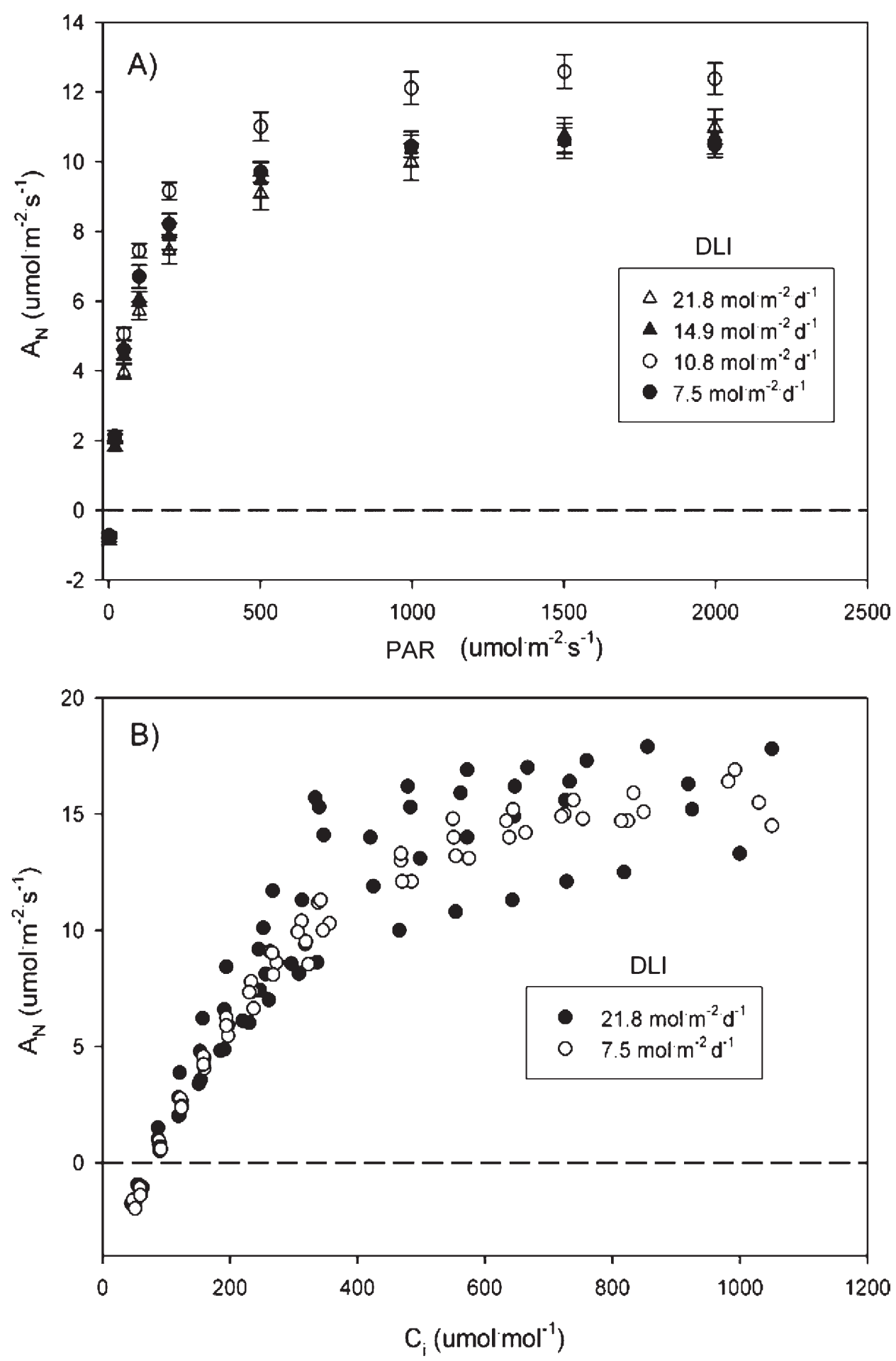

Fig. 6. (A) Photosynthesis - light response curve and (B) internal $\mathrm{CO}_{2}$ response curves for Heuchera americana 'Dale's Strain' grown under four daily light integrals (DLI). Data in (A) represent the mean of four replications with error bars representing the SE. Data in (B) represent individual measurements from four representative samples of the highest and lowest DLI treatments.

under limiting light levels, allowing them to sustain positive rates of carbon assimilation under lower light conditions.

WUE $_{\mathrm{c}}$ increased with shading (Fig. 3C). Others looking at the impact of light on $\mathrm{WUE}_{\mathrm{c}}$ in regard to Solanum lycopersicum (tomato) and Cucumis sativus (cucumber) yield have noted similar trends (Gent, 2008; Lorenzo et al., 2006). Conversely, our $\mathrm{WUE}_{1}$ results showed an inverse trend with efficiency increasing with light level (Fig. 3D). Andersen et al. (1991) observed this trend in final gas exchange measures during a shading study with Aucuba japonica 'Variegata' (gold dust plant). Decreasing $g_{\mathrm{S}}$ without a corresponding change in $A_{N}$ in plants growing under higher irradiance is the cause of increase in $\mathrm{WUE}_{1}$ in our study. As mentioned earlier, a conflict between the two measures of WUE can be the result of several factors including variation in vapor pressure deficits, dry matter allocation, dark respiration rates, changes in $g_{\mathrm{S}}$ throughout the day, changes in canopy architecture, and differences in $g_{\mathrm{S}}$ across a single leaf surface or among different leaves (Kramer and Boyer, 1995).

Very little, if any, water applied to the potted plants was lost to leaching. Therefore, $\mathrm{WUE}_{\mathrm{c}}$ largely accounts for water loss through evaporation directly from the substrate and whole-canopy transpiration losses. DLI treatments did not affect air temperature (mean temperature among all treatments was $21.7^{\circ} \mathrm{C}$ ), but vapor pressure deficit was not monitored under each shade structure. Higher light levels may have increased leaf temperature, which would result in an increase in leafto-air vapor pressure deficit, which would increase transpiration and lower $W_{U E}$ under high DLI. Furthermore, shoot dry weight, which is directly used to calculate $\mathrm{WUE}_{\mathrm{c}}$, increased with increasing DLI. This could largely explain treatment differences in $W_{U E}$. The differences among $\mathrm{WUE}_{\mathrm{c}}$ and $\mathrm{WUE}_{1}$ indicate that caution should be taken when interpreting $\mathrm{WUE}_{1}$ data. Furthermore, it would be valuable to determine which simple, repeatable leaf-level WUE measurements most closely and consistently correlate with canopy-level WUE data.

\section{Conclusions}

Substrate water content and DLI both have a significant impact on the growth and morphology of american alumroot, whereas little plasticity in photosynthetic acclimation was observed. The lack of photosynthetic acclimation in response to drought or high light suggests that this species can tolerate a wide variety of environmental conditions, at least partially because of plasticity in morphological adaptation, but is unable to fully use higher 


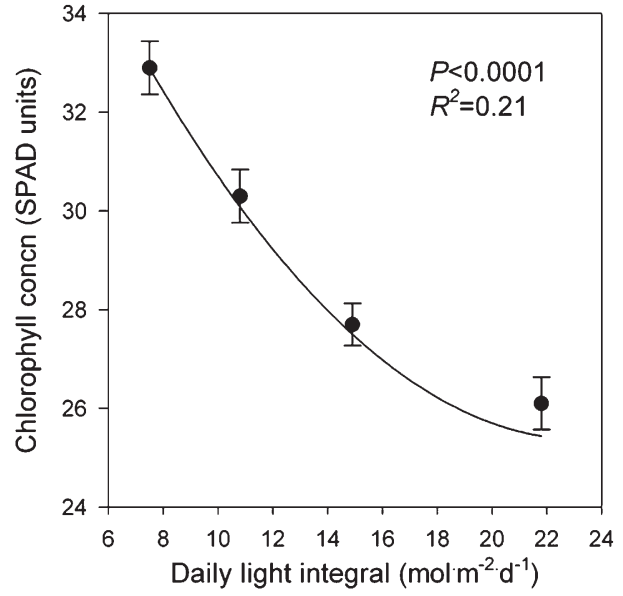

Fig. 7. Chlorophyll concentration of Heuchera americana 'Dale's Strain' grown under four daily light integrals for $45 \mathrm{~d}$. Data represent the mean of 16 replications with error bars representing the SE.

light levels as a result of a limited ability to modify its photosynthetic physiology. Supplemental lighting may be beneficial for american alumroot production in settings where light levels are below $11 \mathrm{~mol} \cdot \mathrm{m}^{-2} \cdot \mathrm{d}^{-1}$ and shading materials should be considered if light levels are beyond $15 \mathrm{~mol} \cdot \mathrm{m}^{-2} \cdot \mathrm{d}^{-1}$ to avoid reductions in leaf area.

American alumroot grows best at $\theta$ between 0.35 and 0.5 $\mathrm{L} \cdot \mathrm{L}^{-1}$, because $\theta$ below this range decreased both leaf area and biomass. Using a capacitance sensor automated irrigation system to irrigate american alumroot would conserve water. Plants irrigated using this system needed no more than $5 \mathrm{~L}$ of water for $56 \mathrm{~d}$, even when they were irrigated at the highest water content $\left(0.5 \mathrm{~L} \cdot \mathrm{L}^{-1}\right)$.

Gas exchange measures of water use efficiency did not accurately reflect whole crop WUE. $\mathrm{WUE}_{1}$ is commonly used to provide insight as to how various abiotic and biotic factors influence how efficiently water is used to produce biomass. These findings demonstrate that there are limitations associated with making such extrapolations from the leaf to the crop level.

\section{Literature Cited}

Andersen, P.C., G.W. Knox, and J.G. Norcini. 1991. Light-intensity influences growth and leaf physiology of Aucuba japonica variegata. HortScience 26:1485-1488.

Bernacchi, C.J., A.R. Portis, H. Nakano, S. von Caemmerer, and S.P. Long. 2002. Temperature response of mesophyll conductance. Implications for the determination of rubisco enzyme kinetics and for limitations to photosynthesis in vivo. Plant Physiol. 130:19921998.

Burnett, S.E., S.V. Pennisi, P.A. Thomas, and M.W. van Iersel. 2005. Controlled drought affects morphology and anatomy of Salvia splendens. J. Amer. Soc. Hort. Sci. 130:775-781.

Burnett, S.E. and M.W. van Iersel. 2008. Morphology and irrigation efficiency of Gaura lindheimeri grown with capacitance-sensor controlled irrigation. HortScience 43:1555-1560.

Burnett, S.E. and M.W. van Iersel. 2012. Watering, irrigation systems, and control. In: K. Williams (ed.). Water and nutrient management for floriculture crops. University of California Press, Berkley, CA (In Press).

Cullina, W. 2000. Growing and propagating wildflowers of the United States and Canada. Houghton Mifflin, Boston, MA, and New York, NY.
Eakes, D.J., R.D. Wright, and J.R. Seiler. 1991. Water relations of Salvia splendens 'Bonfire' as influenced by potassium nutrition and moisture stress conditioning. J. Amer. Soc. Hort. Sci. 116:712715 .

Faust, J.E. 2003. Light, p. 71-84. In: Hamrick, D. (ed.). Ball redbook: Crop production. 17th Ed. Vol. 2. Ball Publishing, Batavia, IL.

Faust, J.E., V. Holcombe, N.C. Rajapakse, and D.R. Layne. 2005. The effect of daily light integral on bedding plant growth and flowering. HortScience 40:645-649.

Fisher, P.R. and A. Both. 2004. Supplemental lighting and energy costs, p. 43-46. In: Fisher, P.R. and E. Runkle (eds.). Lighting up profits: Understanding greenhouse lighting. Meister Media Worldwide, Willoughby, $\mathrm{OH}$.

Flexas, J. and H. Medrano. 2002. Drought-inhibition of photosynthesis in C3 plants: Stomatal and non-stomatal limitations revisited. Ann. Bot. (Lond.) 89:183-189.

Flexas, J., M. Ribas-Carbo, A. Diaz-Espejo, J. Galmes, and H. Medrano. 2008. Mesophyll conductance to $\mathrm{CO}_{2}$ : Current knowledge and future prospects. Plant Cell Environ. 31:602-621.

Franco, J.A., J.J. Martinez-Sanchez, J.A. Fernandez, and S. Banon. 2006. Selection and production of ornamental plants for landscaping and xeroscaping in semi-arid environments. J. Hort. Sci. Biotechnol. 81:3-17.

Gent, M.P.N. 2008. Density and duration of shade affect water and nutrient use in greenhouse tomato. J. Amer. Soc. Hort. Sci. 133:333340.

Givnish, T.J. 1988. Adaption to sun and shade: A whole plant perspective. Aust. J. Plant Physiol. 15:63-92.

Hall, T.J., J.H. Dennis, R.G. Lopez, and M.I. Marshall. 2009. Factors affecting growers' willingness to adopt sustainable floriculture practices. HortScience 44:1346-1351.

Heims, D. and G. Ware. 2005. Heucheras and heucherellas: Coral bells and foamy bells. Timber Press, Portland, OR.

Jones, H.G. 2007. Monitoring plant and soil water status: Established and novel methods revisited and their relevance to studies of drought tolerance. J. Expt. Bot. 58:119-130.

Kim, J. and M.W. van Iersel. 2009. Daily water use of abutilon and lantana at various substrate water contents. Proc. Southern Nursery Assn. Res. Conf. 54:12-16.

Kim, J., M.W. van Iersel, and S.E. Burnett. 2011. Estimating daily water use of two petunia cultivars based on plant and environmental factors. HortScience 46:1287-1293.

Kramer, P.J. and J.S. Boyer. 1995. Water relations of plants and soils. Academic Press, San Diego, CA.

Krug, B.A., S.E. Burnett, J.H. Dennis, and R.G. Lopez. 2008. Growers look at operating a sustainable greenhouse. GMPro 28:43-45.

Lambers, H., T.L. Pons, and S. Chapin. 2008. Plant physiological ecology. 2nd Ed. Springer Verlag, New York, NY.

Long, S.P. and C.J. Bernacchi. 2003. Gas exchange measurements, what can they tell us about the underlying limitations to photosynthesis? Procedures and sources of error. J. Expt. Bot. 54:2393-2401.

Lorenzo, P., M.L. Garcia, M.C. Sanchez-Guerrero, E. Medrano, I. Caparros, and M. Giminez. 2006. Influence of mobile shading on yield, crop transpiration, and water use efficiency. Acta Hort. 719: 471-478.

Mattson, N.S., S.E. Burnett, B.A. Krug, and R.G. Lopez. 2009. Reducing crop shrinkage. Greenhouse Grower 27:26-32.

Miller, A.M., M.W. van Iersel, and A.M. Armitage. 2001. Whole-plant carbon dioxide exchange responses of Angelonia angustifolia to temperature and irradiance. J. Amer. Soc. Hort. Sci. 125:606-610.

Naasz, R., J.C. Michel, and S. Charpentier. 2005. Measuring hysteretic hydraulic properties of peat and pine bark using a transient method. Soil Sci. Soc. Amer. J. 69:13-22.

Nelson, P.V. 2003. Greenhouse operation and management. 6th Ed. Prentice Hall, Upper Saddle River, NJ.

Nemali, K.S. and M.W. van Iersel. 2004. Acclimation of wax begonia to light intensity: Changes in photosynthesis, respiration, and chlorophyll concentration. J. Amer. Soc. Hort. Sci. 129:745-751. 
Nemali, K.S. and M.W. van Iersel. 2006. An automated system for controlling drought stress and irrigation in potted plants. Sci. Hort. 110:292-297.

Nemali, K.S. and M.W. van Iersel. 2008. Physiological responses to different substrate water contents: Screening for high water-use efficiency in bedding plants. J. Amer. Soc. Hort. Sci. 133:333-340.

Niu, G.H., D.S. Rodriguez, and Y.T. Wang. 2006. Impact of drought and temperature on growth and leaf gas exchange of six bedding plant species under greenhouse conditions. HortScience 41:14081411.

Oh, W., I.H. Cheon, K.S. Kim, and E. Runkle. 2009. Photosynthetic daily light integral influences flowering time and crop characteristics of Cyclamen persicum. HortScience 44:341-344.

Osmond, C.B. 1994. What is photoinhibition? Some insights from comparison of shade and sun plants, p. 1-24. In: Baker, N.R. and J.R. Bowyer (eds.). Photoinhibition of photosynthesis: From molecular mechanisms to the field. Bios Scientific, Oxford, UK.

Paul, M. and C.H. Foyer. 2001. Sink regulation of photosynthesis. J. Expt. Bot. 52:1383-1400.

Pearcy, R.W. and W. Yang. 1998. The functional morphology of light capture and carbon gain in the redwood forest understorey plant Adenocaulon bicolor Hook. Funct. Ecol. 12:543-552.

Pennisi, S., M.W. van Iersel, and S.E. Burnett. 2005. Photosynthetic irradiance and nutrition effects on growth of English ivy in subirrigation systems. HortScience 40:1740-1745.

Pierzynski, G.M., J.T. Sims, and G.F. Vance. 2005. Soils and environmental quality. 3rd Ed. Taylor and Francis Group, New York, NY.

Pospíšilová, J. and I.C. Dodd. 2005. Role of plant growth regulators in stomatal limitation to photosynthesis during water stress, p. 811-825. In: Pessarakli, M. (ed.). Handbook of photosynthesis. 2nd Ed. Taylor and Francis Group, Boca Raton, FL.

Prevete, K.J., T. Fernandez, and W.B. Miller. 2000. Drought response of three ornamental herbaceous perennials. J. Amer. Soc. Hort. Sci. 125:310-317.

Prioul, J.L. and P. Chartier. 1977. Partitioning of transfer and carboxylation components of intracellular resistance to photosynthetic $\mathrm{CO}_{2}$ fixation-Critical analysis of methods used. Ann. Bot. (Lond.) 41:789-800.

Ristvey, A.G. and J.D. Lea-Cox. 2008. Wireless moisture sensing for real-time management of irrigation in container nursery operations. 8 Nov. 2011. <http://www.reeis.usda.gov/web/crisprojectpages/210639. html>.

Rothstein, D.E. and D.R. Zak. 2001. Photosynthetic adaptation and acclimation to exploit seasonal periods of direct irradiance in three temperate, deciduous-forest herbs. Funct. Ecol. 15:722-731.
Sánchez-Blanco, M.J., S. Álvarez, A. Navarro, and S. Bañón. 2009. Changes in leaf water relations, gas exchange, growth and flowering quality in potted geranium plants irrigated with different water regimes. J. Plant Physiol. 166:467-476.

Seeman, J.R., T.D. Sharkey, J.L. Wang, and C.B. Osmond. 1987. Environmental effects on photosynthesis, nitrogen-use efficiency, and metabolite pools in leaves of sun and shade plants. Plant Physiol. 84:796-802.

Singh, S.K. and K.R. Reddy. 2011. Regulation of photosynthesis, fluorescence, stomatal conductance and water-use efficiency of cowpea [Vigna unguiculata (L.) Walp.] under drought. J. Photochem. Photobiol. 105:40-50.

Skillman, J.B. and C.B. Osmond. 1998. Influence of nitrogen supply and growth irradiance on photoinhibition and recovery in Heuchera americana (Saxifragaceae). Physiol. Plant. 103:567-573.

Skillman, J.B., B.R. Strain, and C.B. Osmond. 1996. Contrasting patterns of photosynthetic acclimation and photoinhibition in two evergreen herbs from a winter deciduous forest. Oecologia 107:446-455.

Stamm, P. and P.P. Kumar. 2010. The phytohormone signal network regulating elongation growth during shade avoidance. J. Expt. Bot. 61:2889-2903.

Starman, T. and L. Lombardini. 2006. Growth, gas exchange, and chlorophyll fluorescence of four ornamental herbaceous perennials during water deficit conditions. J. Amer. Soc. Hort. Sci. 131:469-475. Terashima, I. and K. Hikosaka. 1995. Comparative ecophysiology of leaf and canopy photosynthesis. Plant Cell Environ. 18:1111-1128.

U.S. Department of Agriculture. 2009. The PLANTS database. 30 Sept. 2009. <http://www.plants.usda.gov/>.

U.S. Government. 2007. U.S. code, title 7, chapter 64: Agricultural research, extension, teaching, subchapter 1: Findings, purposes, and definitions. 27 Aug. 2010. <http://frwebgate.access.gpo.gov/cgi-bin/ getdoc.cgi?dbname=browse_usc\&docid=Cite:+7USC3103 $>$.

van Iersel, M.W., J.G. Kang, and S.E. Burnett. 2010. Growth and water use of petunia as affected by substrate water content and daily light integral. HortScience 45:277-282.

van Volkenburgh, E. 1999. Leaf expansion-An integrating plant behaviour. Plant Cell Environ. 22:1463-1473.

Wallach, R. 2008. Physical characteristics of soilless media, p. 41116. In: Raviv, M. and J.H. Lieth (eds.). Soilless culture: Theory and practice. Elsevier, Amsterdam, The Netherlands.

Yeh, D.M. and H.M. Wang. 2000. Effects of irradiance on growth, net photosynthesis and indoor performance of the shade-adapted plant, maidenhair fern. J. Hort. Sci. Biotechnol. 75:293-298.

Zollinger, N., R. Kjelgren, T. Cerny-Koenig, K. Kopp, and R. Koenig. 2006. Drought response of six ornamental herbaceous perennials. Sci. Hort. 109:267-274. 